Check for updates

Cite this: RSC Adv., 2017, 7, 36482

\title{
Simple and efficient Fmoc removal in ionic liquid $†$
}

\author{
M. L. Di Gioia, (DD *a P. Costanzo, ${ }^{\text {d }}$ A. De Nino, ${ }^{\text {b }}$ L. Maiuolo, ${ }^{b}$ M. Nardi, (D) bc F. Olivito ${ }^{d}$ \\ and A. Procopio ${ }^{d}$
}

A mild method for an efficient removal of the fluorenylmethoxycarbonyl (Fmoc) group in ionic liquid was developed. The combination of a weak base such as triethylamine and $[\mathrm{Bmim}]\left[\mathrm{BF}_{4}\right]$ makes the entire system more efficient for the cleavage at room temperature of various amines and amino acid methyl esters in short reaction times. The procedure works well even in the case of $\mathrm{N}$-Fmoc amino acids bearing acid-sensitive protecting groups and of $\mathrm{N}$-alkylated amino acid methyl esters. The solvent-free condition provides a complementary method for Fmoc deprotection in solution phase peptide synthesis and modern organic synthesis.

Received 19th April 2017

Accepted 14th July 2017

DOI: $10.1039 / \mathrm{c} 7 \mathrm{ra0} 4425 a$

rsc.li/rsc-advances

liquid phase synthesis, nor the use of the conventional solvent DMF due to its low volatility.

\section{Introduction}

Protective group practice represents an imperative strategy in multistep organic synthesis. ${ }^{1}$ Easy protection and deprotection methods are fundamental to enable the construction of chemical bonds and in the presence of pre-existing bonds. ${ }^{2}$ Hence, mild removal methods as well as finding new procedures for deprotection are highly desirable.

The amine group is probably one of the most common functional groups found in biologically important molecules and the 9-fluorenylmethoxycarbonyl (Fmoc) group represents one of the most widely used protecting groups in the masking of amino functionality, finding particular utility in solution- and solid-phase peptide synthesis and chemistry. ${ }^{3}$

The classical means of Fmoc deprotection employ a large excess of a secondary amine, such as piperidine in DMF. ${ }^{4}$ However, piperidine is a controlled substance with usage in the synthesis of narcotic drugs and psychotropic substances, and leads to large amounts of toxic waste $(20-50 \%$ solutions are required). ${ }^{5}$ Similarly, 1,8-diazabicyclo[5.4.0]undec-7-ene in DMF has found extensive usage for deprotection of difficult sequences ${ }^{6}$ but being a strong base $\left(\mathrm{p} K_{\mathrm{a}} 13.5\right)$ it promotes side reactions such as aspartimide formation. ${ }^{7}$ Furthermore, both agents are unfortunately not very suitable in the alternative

${ }^{a}$ Dipartimento di Farmacia e Scienze della Salute e della Nutrizione, Edificio Polifunzionale, Università della Calabria, 87030 Arcavacata di Rende, Cosenza, Italy. E-mail: ml.digioia@unical.it; Tel: +390984493095

${ }^{b}$ Dipartimento di Chimica, Università della Calabria, Cubo 12C, Arcavacata di Rende, CS, Italy

'Dipartimento di Agraria, Università Telematica San Raffaele, Roma, Via di Val Cannuta, 247, 00166, Italy

${ }^{d}$ Dipartimento di Scienze della Salute, Università Magna Graecia, Viale Europa, Germaneto, CZ, Italy

$\dagger$ Electronic supplementary information (ESI) available: Copy of ${ }^{1} \mathrm{H}$ and ${ }^{13} \mathrm{C}$ NMR spectra for compound $N$-acetyl $N$-methyl valine methyl ester. Copy of ${ }^{1} \mathrm{H}$ spectra for $N$-acetyl $N$-methyl isoleucine methyl ester. See DOI: 10.1039/c7ra04425a
Various bases with higher $\mathrm{p} K_{\mathrm{a}}$ values than piperidine can remove the Fmoc group with high efficacy though some of these bases induce side reactions and require enormous quantities of solvent. Consequently, there is an ongoing effort to search for reagents and solvents that are easily removable during mandatory intermediates isolation. ${ }^{8-10}$

With the increase in environmental concerns and governmental legislation, in order to meet the principles of green chemistry, the development of environmentally benign organic reactions has become a crucial and demanding research area in the modern chemical sciences. ${ }^{11}$ Thus, the development of an environmentally benign, efficient and simple methodology for a fundamental organic transformation is in great demand.

In this context, synthetic manipulations should be made to reduce the use of harmful compounds and volatile organic solvents in reactions, and their subsequent work-up.

Ionic liquids have attracted extensive research interest in recent years as an eco-friendly alternative to replace conventional organic solvents owing to their unique properties, such as non-inflammability, low volatility, negligible vapour pressure, reusability and high thermal stability. To date, many roomtemperature ionic liquids (RTILs) have been used as solvents for several organic transformations. ${ }^{12}$

Among RTILs, ionic liquids containing imidazolium cations are typical since they are easily synthesized and as a powerful reaction media or catalyst show good performance in many reactions. ${ }^{13}$

Our recent interest has been in the development of new synthetic methods using ionic liquids as reaction media for the introduction and removal of different protecting groups. ${ }^{14}$

In this manuscript, we envisaged that the combination of a cheap, nontoxic and readily available amine such as triethylamine and an imidazolium-based IL could be appropriately 
adapted to fulfil the above requirements for the removal of the Fmoc protecting group.

Herein, we demonstrate a very simple method of cleavage by employing triethylamine in $[\mathrm{Bmim}]\left[\mathrm{BF}_{4}\right]$ as recyclable reaction media, which will be a valuable addition to the existing Fmoc removal methods.

\section{Results and discussion}

In our initial experiments, we choose $N$-Fmoc aniline as a model substrate and the results for development and optimization of the deprotection studies are displayed in Table 1.

On treatment of the $N$-Fmoc aniline $(1 \mathrm{mmol})$ with $1 \mathrm{~mL}$ of $[\mathrm{Bmim}]\left[\mathrm{BF}_{4}\right]$ ionic liquid at room temperature, the deprotection did not take place (Table 1, entry 1). However, on adding $3 \mathrm{mmol}$ of triethylamine, deprotection was smoothly accomplished after only $5 \mathrm{~min}$ in $90 \%$ yield (Table 1 , entry 2 ). TLC analysis and ninhydrin assay confirmed the cleavage of the $\mathrm{N}$ Fmoc group. Usage of less $\mathrm{Et}_{3} \mathrm{~N}$ slowed down the reaction rate (5 h) and yield (Table 1 , entry 3 ).

Changing the IL for a conventional solvent such as dichloromethane results in incomplete conversion after $6 \mathrm{~h}$. The low yield (entries 4, Table 1 ) of the reaction conducted in DCM as the conventional solvent provides confirmation of the literature data, ${ }^{15}$ which reports that the cleavage of the Fmoc group by triethylamine in traditional organic solvents occurs very slowly (after 1080 min of reaction). This indicates that the reaction is probably strongly affected by the ionic liquid, which assists the process during the abstraction of the fluorenyl proton, enhancing the amine basicity. ${ }^{16}$ In addition, the ionic liquid has a stabilizing effect on the charged intermediates during the Fmoc removal.

Next, we tested other imidazolium based ionic liquids with basic properties for this transformation to avoid the use of $\mathrm{Et}_{3} \mathrm{~N}$ in the reaction system. Employing 1-methyl-3-butyl imidazolium chloride ([Bmim][Cl]) or 1-methyl-3-butyl imidazolium hydroxide $([\mathrm{Bmim}][\mathrm{OH}])$ as the solvent, catalyst and base in the deprotection reaction, the yields were low and the reaction

Table 1 Optimization of conditions for the cleavage of the Fmoc $\operatorname{group}^{a}$

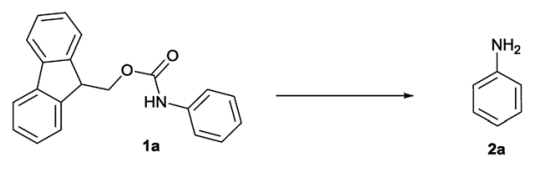

\begin{tabular}{llllll}
\hline Entry & Solvent & Base & Temp. $\left({ }^{\circ} \mathrm{C}\right)$ & Time $($ min $)$ & Yield $^{b}(\%)$ \\
\hline 1 & {$[\mathrm{Bmim}]\left[\mathrm{BF}_{4}\right]$} & - & 25 & 300 & 0 \\
2 & $\left.\left[\mathrm{Bmim}_{[}\right] \mathrm{BF}_{4}\right]$ & $\mathrm{Et}_{3} \mathrm{~N}$ & 25 & 5 & 90 \\
$3^{c}$ & {$[\mathrm{Bmim}]\left[\mathrm{BF}_{4}\right]$} & $\mathrm{Et}_{3} \mathrm{~N}$ & 25 & 300 & 62 \\
$4^{d}$ & $\mathrm{DCM}$ & $\mathrm{Et}_{3} \mathrm{~N}$ & 25 & 360 & 10 \\
5 & {$[\mathrm{Bmim}][\mathrm{Cl}]$} & - & 80 & 240 & 30 \\
6 & {$[\mathrm{Bmim}][\mathrm{OH}]$} & - & 80 & 240 & 45
\end{tabular}

${ }^{a}$ Reaction conditions: Fmoc-aniline ( $\left.1 \mathrm{mmol}\right), \mathrm{Et}_{3} \mathrm{~N}(3 \mathrm{mmol})$ in $1 \mathrm{~mL}$ of solvent. ${ }^{b}$ Isolated yield. ${ }^{c} 1 \mathrm{mmol}$ of $\mathrm{Et}_{3} \mathrm{~N}$. ${ }^{d} 5 \mathrm{~mL}$ of DCM were used. times long (Table 1, entries 5 and 6). Furthermore, the use of these basic ILs required severe conditions of high temperature.

We found that the best results in terms of reaction rate $(5$ $\mathrm{min}$ ) and product yield were the use $3 \mathrm{mmol} \mathrm{Et}_{3} \mathrm{~N}$ in [Bmim] $\left[\mathrm{BF}_{4}\right]$ at room temperature (entry 2, Table 1).

It is well known that during the deprotection of the Fmoc group, dibenzofulvene (DBF) is a by-product that needs to be efficiently removed. Particularly in peptide synthesis, a dibenzofulvene amine adduct can be responsible for side reactions. ${ }^{\mathbf{1 0}}$ To prevent the formation of this undesired by-product, after the extraction of the free aniline from $\left[\mathrm{Bmim}^{\mathrm{B}}\right]\left[\mathrm{BF}_{4}\right]$ with diethyl ether, we added an aqueous $1 \mathrm{~N} \mathrm{HCl}$ solution to protonate the amine. The undesired DBF was thus removed by diethyl ether extraction and the protonated aniline remained in the aqueous solution. The collected aqueous solution was then basified to neutral to give the native amine, which was finally recovered in ethereal solution.

Encouraged by the optimized solvent-free ionic liquidcatalyzed method for the deprotection of Fmoc-aniline, we applied the strategy to various Fmoc-protected aliphatic linear and cyclic amines (Table 2). The reactions carried out in [Bmim] $\left[\mathrm{BF}_{4}\right]$ at room temperature afforded the corresponding free amines in excellent yields and with short reaction times (4-8 $\min )$.

We observed that $N$-Fmoc-protected $p$-toluidine or derivatives of benzylamine easily undergo deprotection under the selected reaction conditions to afford the desired amines in excellent yields (Table 2).

The method is also applicable for deprotection of $\mathrm{N}$-Fmocprotected aliphatic amines: the cleavage of $N$-Fmoc cyclopentylamine and 2-phenylethylamine (Table 2, entries 6 and 7) proceeded efficiently in high yields. The removal of the Fmoc group from secondary cyclic amines took a shorter reaction time and gave almost quantitative yields (Table 2, entries 8-9). It is evident that the resonance and inductive effects of the substituent groups on the tested amines have no influence on the Fmoc removal.

Considering the importance of the $N$-Fmoc protection strategy in peptide synthesis, we next examined the feasibility of $N$-Fmoc deprotection of amino acids. Therefore, the developed method was used in a series of lipophilic Fmoc-protected amino acid methyl esters $(\mathbf{1 j} \mathbf{j} \mathbf{- 1 n}$, Table 3$)$.

In order to demonstrate the successful removal of the Fmoc group in IL, compounds $\mathbf{1 j} \mathbf{j} \mathbf{- 1 n}$ were characterized by GC/MS after their conversion into the corresponding $\mathrm{N}$-acetyl derivatives by treatment with acetic anhydride under Schotten-Baumann conditions. Racemization at the $\alpha$-carbon of the amino acid derivatives was not observed in any cases.

The stereochemical integrity was studied by chiral GC analysis. To this end, compound $\mathbf{2 j}$ (Table 3 ) obtained by ILmediated Fmoc deprotection was acetylated to get Ac-L-AlaOMe and compared with the methyl ester of DL-alanine opportunely acetylated. In Fig. 1 (panel a) two peaks were observed, which clearly show different retention times for the two enantiomers, Ac-D-Ala-OMe and Ac-L-AlaOMe. Instead, the chiral GC analysis of acetylated Ac-L-Ala-OMe revealed the presence of only one peak, thus strongly supporting the chiral integrity 
Table 2 Ionic liquid-catalyzed deprotection of $\mathrm{N}$-Fmoc-amines ${ }^{a}$

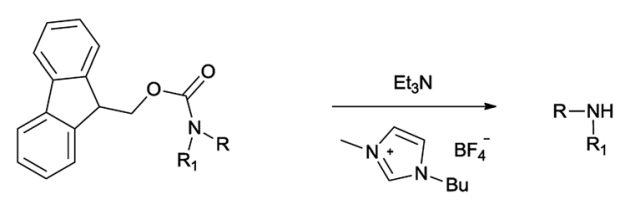

\begin{tabular}{llll}
\hline Entry & $N$-Fmoc-amine & Product & Time $(\min )^{\text {Yield }}{ }^{b}(\%)$ \\
\hline
\end{tabular}

1

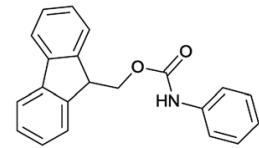

1a

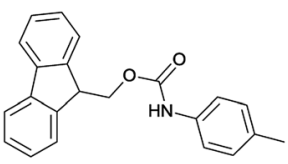

1b

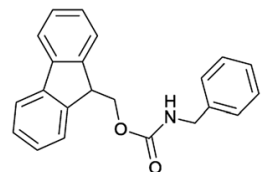

$1 c$<smiles></smiles><smiles>O=C(NCCc1ccccc1)OCC1c2ccccc2-c2ccccc21</smiles>

$1 \mathrm{e}$<smiles>O=C(NC1CCCC1)OCC1c2ccccc2-c2ccccc21</smiles>

1f<smiles>O=C(OCC1c2ccccc2-c2ccccc21)N1CCOCC1</smiles>

$1 \mathrm{~g}$<smiles>O=C(OCC1c2ccccc2-c2ccccc21)N1CCCC1</smiles>

$1 \mathrm{~h}$<smiles>O=C(OCC1c2ccccc2-c2ccccc21)N1CCCCC1</smiles>

1i

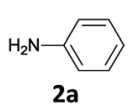

$90^{c}$

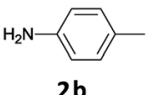

6

91<smiles>NCc1ccccc1</smiles>

5

85<smiles>COc1ccc(CN)cc1</smiles>

8

80<smiles>NCCc1ccccc1</smiles>

$2 e$

7

82<smiles>NC1CCCC1</smiles>

7

92<smiles></smiles>

4

93<smiles></smiles>

4

93<smiles>C1CCNCC1</smiles>

\footnotetext{
${ }^{a}$ Reaction conditions: Fmoc-amine $(1 \mathrm{mmol}), \mathrm{Et}_{3} \mathrm{~N}(3 \mathrm{mmol}),[\mathrm{Bmim}]\left[\mathrm{BF}_{4}\right](1 \mathrm{~mL})$ for $3-8 \mathrm{~min}$ at $25{ }^{\circ} \mathrm{C}$. The free amine was obtained after a simple extraction procedure with diethyl ether from the ionic liquid and an appropriate work-up to remove the resultant dibenzofulvene. ${ }^{b}$ Isolated yields after work-up. ${ }^{c}$ Yield of the first of three runs using the same recovered IL. Yields of the subsequent runs were 88 and $89 \%$, respectively.
} 
Paper

View Article Online

RSC Advances

Table 3 Scope for the deprotection of $N$-Fmoc amino acid methyl esters ${ }^{a}$

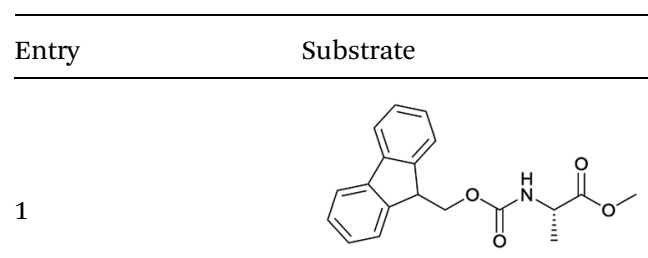

$\mathbf{1 j}$

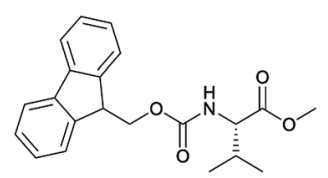

3

4

5

6

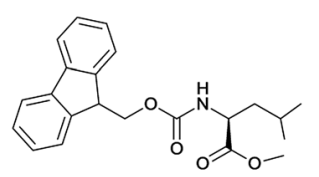

Il

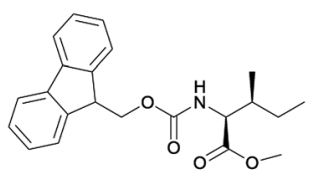

$1 \mathrm{~m}$

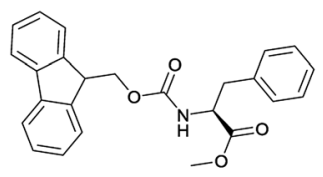

In

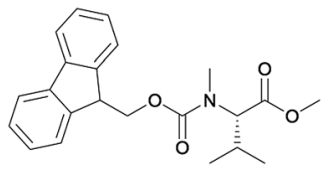

10

7

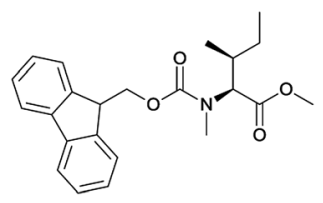

8

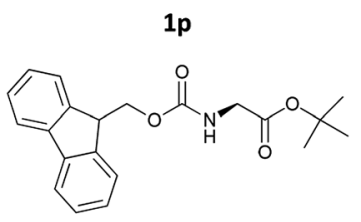

$1 q$

9

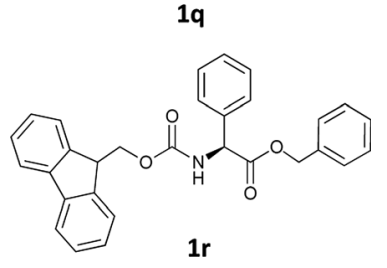

Product

Time (min)

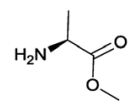

2j

8

88

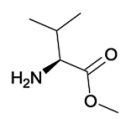

10

86

$2 \mathrm{k}$

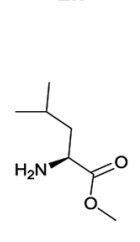

Yield $^{b}(\%)$

II

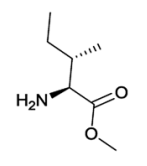

10

81

10

79

$2 m$

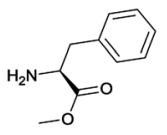

10

82

12

75

20<smiles>CCC(C)[C@H](NC)C(=O)OC</smiles>

15

83

$2 p$

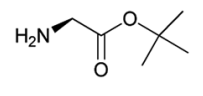

$2 q$

13

82

15

85

This journal is (c) The Royal Society of Chemistry 2017

RSC Adv., 2017, 7, 36482-36491 | 36485 
Table 3 (Contd.)

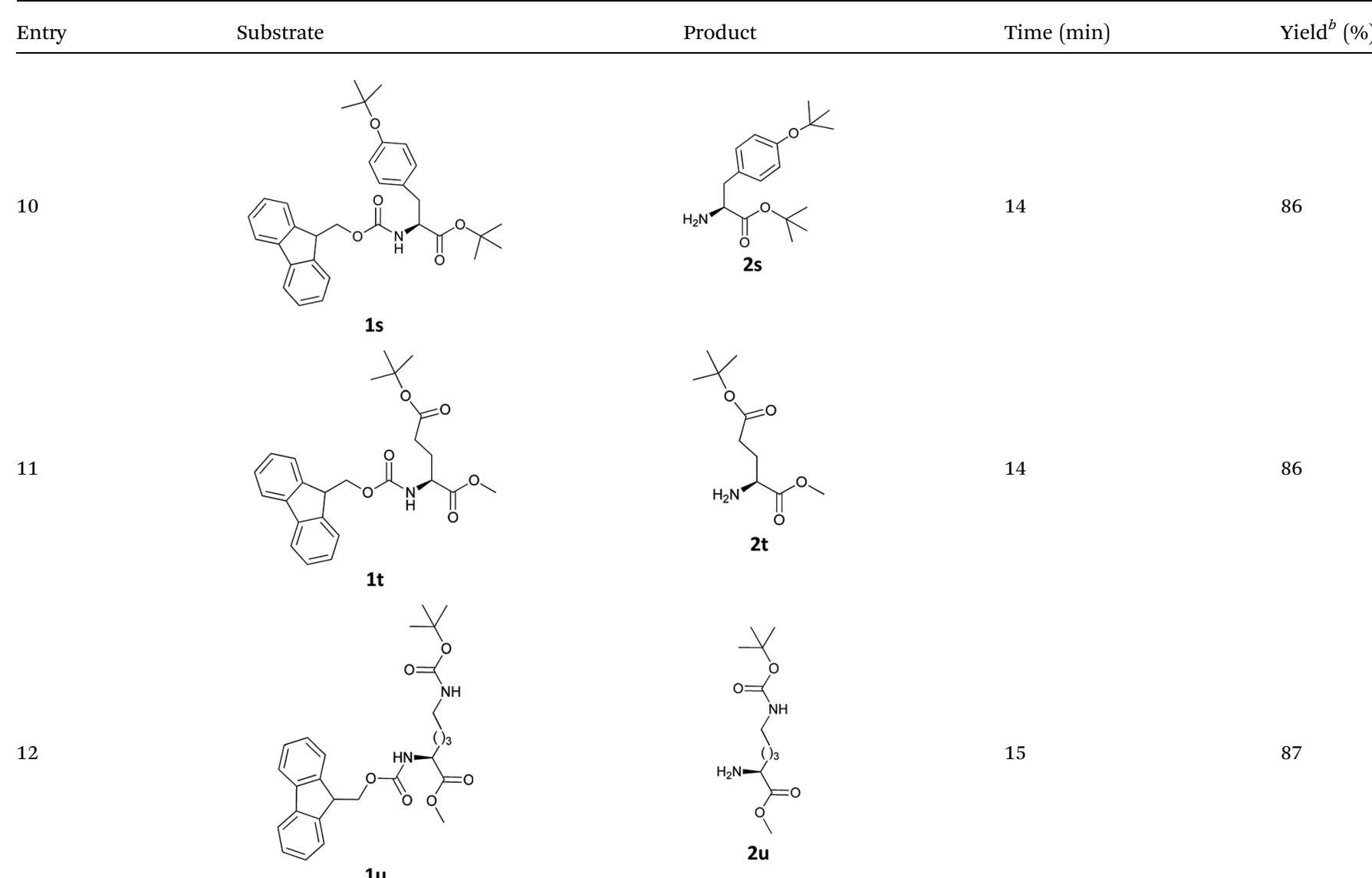

$1 \mathbf{u}$

\begin{abstract}
${ }^{a}$ Reaction conditions: Fmoc-amine (1 mmol), $\mathrm{Et}_{3} \mathrm{~N}(3 \mathrm{mmol}),[\mathrm{Bmim}]\left[\mathrm{BF}_{4}\right](1 \mathrm{~mL})$ for $5-8 \mathrm{~min}$ at $25{ }^{\circ} \mathrm{C}$. The free amino acid was obtained after a simple extraction procedure with diethyl ether from the ionic liquid and an appropriate work-up to remove the resultant dibenzofulvene. The free amino acids were characterized by GC/MS analysis after acetylation. ${ }^{b}$ Isolated yields after work-up.
\end{abstract}

without undesired racemization (Fig. 1, panel b). Therefore, the treatment with $\mathrm{Et}_{3} \mathrm{~N}$ in $[\mathrm{Bmim}]\left[\mathrm{BF}_{4}\right]$ induced no racemization in the Fmoc deprotection process of amino acids.

The applicability of this method was then tested for a set of $N$-Fmoc-amino acids containing functionalized side chains with acid-labile protecting groups (e.g., $t$-Bu, Boc, benzyl) to make the adopted procedure useful for peptide synthesis.

In particular, we selected the masking groups commonly used during peptide synthesis that are orthogonal to the Fmoc group (see Table 3, entries 8-12). In addition, in this case, the Fmoc-amino acids we checked gave high yields of the corresponding derivatives unmasked on the $\alpha$-amino function (Table 3 , entries 8-12) and the acid-labile protective groups of all the products obtained remained intact at the end of the process.

To avoid undesired removal of the acid-sensitive side chain protecting groups, the work-up of the ethereal extract from IL was performed with a $5 \%$ solution of citric acid.

The times required for the cleavage were short and no chromatographic purification was necessary.

The methodology is also successful when applied to $N$-Fmoc amino acid benzyl and tert-butyl esters (Table 3, entries 8-10).
Finally, we tested our procedure for the N-deprotection of $\mathrm{N}$ Fmoc- $N$-alkyl amino acid derivatives.

$N$-Methyl- $\alpha$-amino acids are very important building blocks in the synthesis of peptidomimetics, covering an important role in medicinal chemistry. ${ }^{17}$ Many efforts have been directed at optimizing strategies for their synthesis and use in peptide chemistry. ${ }^{18}$

We were delighted to observe that the $N$-amino group was easily deprotected when two different $N$-Fmoc- $N$-alkylatedamino acid methyl esters (1o and 1p, Table 3) were treated with triethylamine in $[\mathrm{Bmim}]\left[\mathrm{BF}_{4}\right]$ ionic liquid at room temperature. As already described above, a conventional acidbase work-up was employed for these analogues to remove the side product (i.e., DBF) formed during the process. The $\mathrm{N}$ deprotected- $N$-alkylated products were obtained in good yields (entries 6 and 7, Table 3). The chemical yields of 20 (entry 6 in Table 3) were not so high (75\%) compared to the other products. The possible explanation for this low yield compared to the other products lies in the steric bulk of $N$-alkyl amino acids, which reduces the reaction rate and leads to undesirable byproducts. 

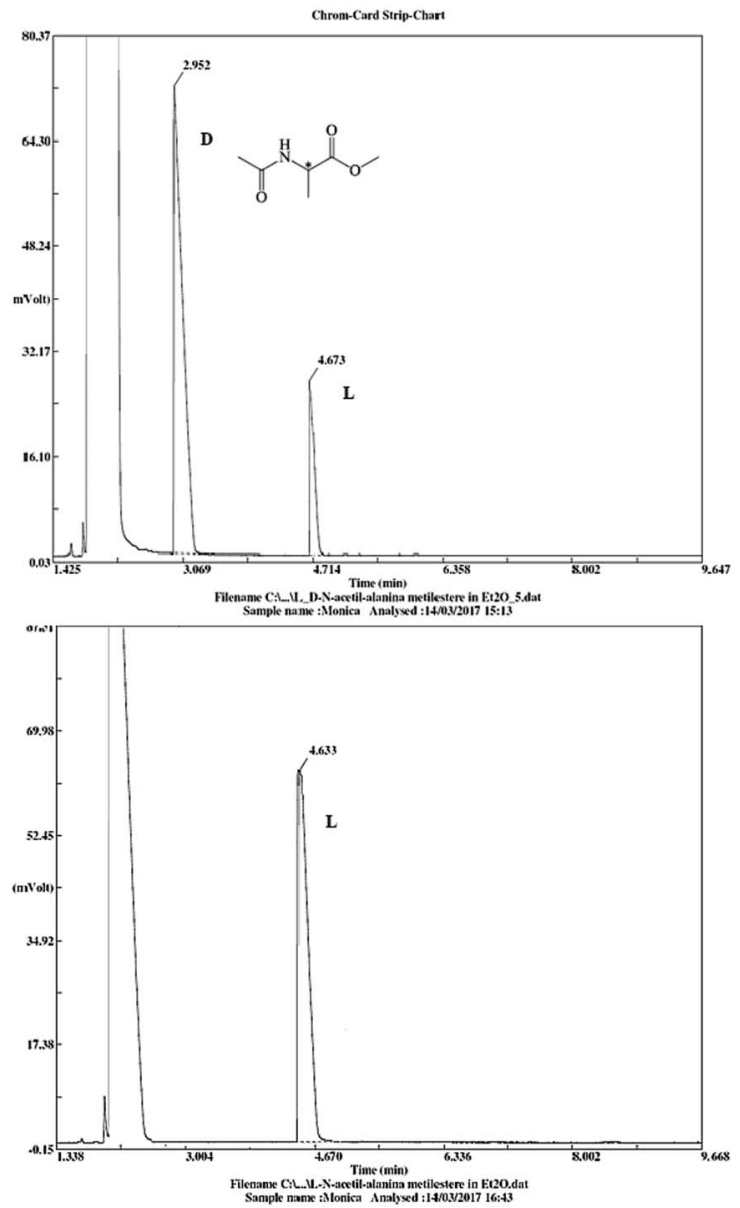

Fig. 1 Chiral GC data for AC-DL-Ala-OMe and Ac-L-Ala-OMe $(25 \mathrm{~m} \times$ $0.25 \mathrm{~mm}$, diethyl tert-butyldimethylisilyl- $\beta$-cyclodextrin chiral capillary column).

The Fmoc protecting group is widely used in solid phase peptide synthesis and its removal is generally accomplished by treatment with piperidine $(20-50 \%)$ in DMF. ${ }^{4}$ Although highly successful and readily automated, solid-phase synthesis suffers a series of problems due to the heterogeneous reaction conditions, such as the huge amount of solvent required during preparation or purification steps. Thus, alternative, more environmentally friendly liquid phase methodologies are particularly desirable to restore homogeneous reaction conditions and the ionic liquids could be particularly suitable for amino acid and peptide synthesis or transformations since the polarity of ionic solvents is ideal for such species.

In this context, our research report proposes the use of ionic liquids as alternative green solvents in peptide synthesis according to the Fmoc-strategy in homogeneous conditions. ${ }^{19}$ Important advantages of our method are the absence of organic solvents, easy work-up, and the possibility to recycle the ionic liquid. Additionally, the solid support bearing the growing peptide chain would turn out to be inseparable from the ionic liquid phase. Thus, the proposed method should be considered as an alternative to the solid-phase synthesis of peptides.
Indeed, in other ways, almost simultaneously with the demonstration that ionic liquids were particularly convenient solvents for peptide coupling, ${ }^{20}$ a number of recent reports propose new insights into supported peptide synthesis where strategies in which peptide elongation could be performed on immobilized species using ionic liquid moieties as the soluble support are proposed. In that case, the IL-supported species can be dissolved in a solvent, and the reaction can be conducted in a homogeneous solution as an alternative to the solid-phase peptide synthesis. ${ }^{21}$

In view of green chemistry, one of the important features of the reactions conducted in ionic medium is the possibility of reuse the catalytic system for the subsequent runs with only a gradual decrease in activity and with no production of waste. ${ }^{11}$

We investigated the recycling capability of $[\mathrm{Bmim}]\left[\mathrm{BF}_{4}\right]$ in the deprotection of the Fmoc group. After extraction with $\mathrm{Et}_{2} \mathrm{O}$ to separate the products from the reaction mixture, the residual ionic liquid was directly reused for the next deprotection. The results are displayed in Table 2 and show a slight decrease in the yield after the third recycling, indicating no significant loss of efficiency of the ionic liquid. The results of the presented protocol show that $\mathrm{Et}_{3} \mathrm{~N} /\left[\mathrm{Bmim}^{-}\right]\left[\mathrm{BF}_{4}\right]$ is an efficient reagent system to remove the Fmoc group.

\section{Conclusions}

The use of greener and more efficient methodologies for organic transformations is fundamental for the development of more sustainable processes.

We have reported a simple and convenient protocol based on the use of $[\mathrm{Bmim}]\left[\mathrm{BF}_{4}\right]$ and the easily accessible triethylamine for the deprotection of Fmoc amines and amino acid methyl esters.

Important advantages of this method are: absence of organic solvents, use of a weak, inexpensive and readily available base such as $\mathrm{Et}_{3} \mathrm{~N}$, short reaction times, high yields, easy work-up, and finally the possibility to recycle the ionic liquid.

The procedure is also advantageous in that it avoids any hazardous chemicals. The protocol is an improvement over the existing methodologies for the removal of the Fmoc protecting group in solution phase.

\section{Experimental section}

\section{General}

Commercially available reagents were purchased from SigmaAldrich Chemical Co. (Milano, Italy) and used as supplied unless stated otherwise. All syntheses were carried out in atmospheric conditions. ${ }^{1} \mathrm{H}$ NMR spectra were recorded at 300 $\mathrm{MHz}$, while ${ }^{13} \mathrm{C}$ NMR spectra were measured at $75 \mathrm{MHz}$. Spectral analysis was performed at $293 \mathrm{~K}$ on diluted solutions of each compound by using $\mathrm{CDCl}_{3}$ as the solvent. Chemical shifts $(\delta)$ are reported in ppm and referenced to $\mathrm{CDCl}_{3}\left(7.25 \mathrm{ppm}\right.$ for ${ }^{1} \mathrm{H}$ and $77.0 \mathrm{ppm}$ for ${ }^{13} \mathrm{C}$ spectra). Coupling constants $(J)$ are reported in hertz $(\mathrm{Hz})$. Reaction mixtures were monitored by thin layer chromatography (TLC) using Merck Silica gel 60- $\mathrm{F}_{254}$ precoated glass plates, and UV light $(254 \mathrm{~nm})$ or $0.2 \%$ ninhydrin in ethanol 
and charring reagent as the visualizing agent. Evaporation of solvents was performed at reduced pressure using a rotary vacuum evaporator. Chiral GC analyses were carried out using a Thermo Gas Chromatograph instrument. Chiral GC analyses of enantiomeric compounds Ac-DL-AlaOMe and Ac-L-AlaOMe were performed using a $25 \mathrm{~m} \times 0.25 \mathrm{~mm}$, diethyl tert-butyldimethylisilyl- $\beta$-cyclodextrin chiral capillary column. The GC-MS Shimadzu workstation constituted a GC 2010 (equipped with a 30 m-QUADREX 007-5MS capillary column, operating in

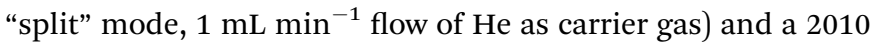
quadrupole mass-detector. LC-MS analyses were carried out using an Agilent 6540 UHD Accurate-Mass Q-TOF LC-MS (Agilent, Santa Clara, CA) fitted with an electrospray ionisation source (Dual AJS ESI) operating in positive ion mode. Chromatographic separation was achieved using a C18 RP analytical column (Poroshell 120, SB-C18, $50 \times 2.1 \mathrm{~mm}, 2.7 \mu \mathrm{m}$ ) at $30{ }^{\circ} \mathrm{C}$ with an elution gradient from $5 \%$ to $95 \%$ of $\mathrm{B}$ over $13 \mathrm{~min}$, A being $\mathrm{H}_{2} \mathrm{O}(0.1 \% \mathrm{FA})$ and $\mathrm{B} \mathrm{CH}_{3} \mathrm{CN}(0.1 \% \mathrm{FA})$. The flow rate was $0.4 \mathrm{~mL} \min ^{-1}$.

$N$-Fmoc amines 1a-i and $N$-Fmoc $\alpha$-amino acid methyl esters 1j-u were prepared according to a previously published protocol. ${ }^{14 b}$ Spectral data of 1a-p agreed with those already reported for the same compounds prepared previously. ${ }^{14 b}$

$\boldsymbol{N}$-(9-Fluorenylmethoxycarbonyl)glycine $\boldsymbol{t}$-butyl ester $(\mathbf{1 q}) \cdot{ }^{1} \mathrm{H}$ NMR $\left(300 \mathrm{MHz}, \mathrm{CDCl}_{3}, 25{ }^{\circ} \mathrm{C}\right): \delta=7.68-7.52(\mathrm{~m}, 4 \mathrm{H}, \mathrm{ArH}), 7.32-$ $7.22(\mathrm{~m}, 4 \mathrm{H}, \mathrm{Ar} H), 6.38$ (br s, $1 \mathrm{H}, \mathrm{NH}), 3.97$ (t, $J=6.0 \mathrm{~Hz}, 1 \mathrm{H}$, $\left.\mathrm{CH}_{\text {Fmoc }}\right), 3.82\left(\mathrm{~d}, J=5.1 \mathrm{~Hz}, 2 \mathrm{H}, \mathrm{CH}_{2 \mathrm{Fmoc}}\right), 3.23\left(\mathrm{~s}, 2 \mathrm{H}, \mathrm{CH}_{2}\right), 1.38$ $\left(\mathrm{s}, 9 \mathrm{H}, \mathrm{C}\left(\mathrm{CH}_{3}\right)_{3}\right)$ ppm. ${ }^{13} \mathrm{C} \mathrm{NMR}\left(75 \mathrm{MHz}, \mathrm{CDCl}_{3}, 25{ }^{\circ} \mathrm{C}\right): \delta=$ $171.8,8,156.1,145.9,141.9$, 128.9, 127.5, 124.8, 120.2, 81.4, $52.7,42.4,31.7,28.3$. HRMS (ESI) for $\left[\left(\mathrm{C}_{21} \mathrm{H}_{13} \mathrm{NO}_{4}\right)+\mathrm{Na}\right]^{+}$: calcd 376.1525, found $376.1518(\mathrm{M}+\mathrm{Na})^{+}$.

$\mathrm{N}$-(9-Fluorenylmethoxycarbonyl)phenylalanine benzyl ester (1r). ${ }^{1} \mathrm{H} \mathrm{NMR}\left(300 \mathrm{MHz}, \mathrm{CDCl}_{3}, 25{ }^{\circ} \mathrm{C}\right): \delta=7.78(\mathrm{~d}, J=7.2 \mathrm{~Hz}$, $2 \mathrm{H}, \operatorname{Ar} H), 7.62(\mathrm{~d}, J=7.2 \mathrm{~Hz}, 2 \mathrm{H}, \operatorname{Ar} H), 7.35-7.17(\mathrm{~m}, 12 \mathrm{H}, \operatorname{Ar} H)$, 7.00-6.97 (m, 2H, $\mathrm{ArH}+\mathrm{NH}), 5.12(\mathrm{dd}, J=12.0 \mathrm{~Hz}, J=9.6 \mathrm{~Hz}$, $1 \mathrm{H}, \alpha-\mathrm{CH}), 4.82-4.79\left(\mathrm{~m}, 2 \mathrm{H}, \mathrm{OCH}_{2} \mathrm{Ph}\right), 4.14\left(\mathrm{~m}, 1 \mathrm{H}, \mathrm{CH}_{\mathrm{Fmoc}}\right)$, 4.10-4.04 (m, 2H, $\mathrm{CH}_{2 \mathrm{Fmoc}}$ ), 3.01-3.05 (m, 2H, $\left.\mathrm{CH}_{2} \mathrm{Ph}\right) \mathrm{ppm} .{ }^{13} \mathrm{C}$ NMR (75 MHz, $\left.\mathrm{CDCl}_{3}, 25{ }^{\circ} \mathrm{C}\right): \delta=172.1,8,158.6,144.2,141.6$, $137.0,136.0$, 135.9, 129.4, 128.6, 128.5, 128.4, 127.6, 126.9, 124.7, 120.0. HRMS (ESI) for $\left[\left(\mathrm{C}_{31} \mathrm{H}_{27} \mathrm{NO}_{4}\right)+\mathrm{Na}\right]^{+}$: calcd 500.1838 , found $500.1824(\mathrm{M}+\mathrm{Na})^{+}$.

$\boldsymbol{N}$-(9-Fluorenylmethoxycarbonyl)tyrosine $(O$ - $t$-butyl $) \boldsymbol{t}$-butyl ester (1s). ${ }^{1} \mathrm{H}$ NMR $\left(300 \mathrm{MHz}, \mathrm{CDCl}_{3}, 25{ }^{\circ} \mathrm{C}\right): \delta=7.75(\mathrm{~d}, 2 \mathrm{H}, J=$ 7.5, $\mathrm{ArH}$ ), 7.58 (d, 2H, $=7.4, \operatorname{Ar} H$ ), 7.42-7.31 (m, 4H, $\mathrm{ArH}), 7.11-$ $7.03(\mathrm{~m}, 2 \mathrm{H}, \operatorname{Ar} H)$, 6.93-6.88 (m, 2H, $\operatorname{Ar} H), 5.30(\mathrm{~d}, 1 \mathrm{H}, J=$ $8.4 \mathrm{~Hz}, \mathrm{NH}), 4.54-4.39\left(\mathrm{~m}, 3 \mathrm{H}, \alpha-\mathrm{C} H+\mathrm{CH}_{2 \mathrm{Fmoc}}\right), 4.34(\mathrm{t}, 1 \mathrm{H}, J=$ 8.6, $\mathrm{CH}_{\text {Fmoc }}$ ), $3.04\left(\mathrm{~m}, 1 \mathrm{H}, \beta-\mathrm{CH}_{2}\right), 2.80\left(\mathrm{~m}, 1 \mathrm{H}, \beta-\mathrm{CH}_{2}\right), 1.40(\mathrm{~s}$, 9H, $\left.\mathrm{C}\left(\mathrm{CH}_{3}\right)_{3}\right), 1.39\left(\mathrm{~s}, 9 \mathrm{H}, \mathrm{C}\left(\mathrm{CH}_{3}\right)_{3}\right) \mathrm{ppm} .{ }^{13} \mathrm{C} \mathrm{NMR}(75 \mathrm{MHz}$, $\left.\mathrm{CDCl}_{3}, 25^{\circ} \mathrm{C}\right): \delta=170.6,155.5,154.2,144.5,143.9,134.6,129.1$, 127.7, 127.0, 124.3, 120.3, 119.7, 82.6, 81.1, 66.9, 55.2, 47.3, 37.9, 28.8, 27.9. HRMS (ESI) for $\left[\left(\mathrm{C}_{32} \mathrm{H}_{37} \mathrm{NO}_{5}\right)+\mathrm{H}\right]^{+}$: calcd 516.2750, found $516.2664,538.2570(\mathrm{M}+\mathrm{Na})^{+}$.

$\mathbf{N}$-(9-Fluorenylmethoxycarbonyl)glutamic acid(O-tert-butyl) methyl ester (1t). ${ }^{1} \mathrm{H} \mathrm{NMR}\left(300 \mathrm{MHz}, \mathrm{CDCl}_{3}, 25^{\circ} \mathrm{C}\right): \delta=7.69(\mathrm{~d}, J$ $=7.5 \mathrm{~Hz}, 2 \mathrm{H}, \operatorname{Ar} H), 7.52(\mathrm{~d}, J=4.8 \mathrm{~Hz}, 2 \mathrm{H}, \operatorname{Ar} H), 7.35-7.21(\mathrm{~m}$, $4 \mathrm{H}, \operatorname{Ar} H), 5.42(\mathrm{~d}, J=8.1 \mathrm{~Hz}, 1 \mathrm{H}, \mathrm{NH}), 4.74-4.38(\mathrm{~m}, 3 \mathrm{H}, \alpha-\mathrm{CH}+$ $\mathrm{CH}_{2 \mathrm{Fmoc}}$ ), $3.68\left(\mathrm{~s}, 3 \mathrm{H}, \mathrm{OCH}_{3}\right), 2.32-2.22\left(\mathrm{~m}, 2 \mathrm{H}, \beta-\mathrm{CH}_{2}\right), 2.13(\mathrm{~m}$,
1H, $\gamma-\mathrm{CH}), 2.06(\mathrm{~m}, 1 \mathrm{H}, \gamma-\mathrm{CH}), 1.37\left(\mathrm{~s}, 9 \mathrm{H}, \mathrm{C}\left(\mathrm{CH}_{3}\right)_{3}\right) \mathrm{ppm} .{ }^{13} \mathrm{C}$ NMR (75 MHz, $\left.\mathrm{CDCl}_{3}, 25{ }^{\circ} \mathrm{C}\right): \delta=171.4,170.9,154.9,142.7$, 140.3, 126.6, 126.0, 124.0, 118.9, 79.8, 66.0, 52.4, 51.4, 46.1, 30.4, 27.0, 26.2 HRMS (ESI) for $\left[\left(\mathrm{C}_{25} \mathrm{H}_{29} \mathrm{NO}_{6}\right)+\mathrm{H}\right]^{+}$: calcd 440.2073, found 440.2135, 462.1891 $(\mathrm{M}+\mathrm{Na})^{+}$.

$\boldsymbol{N}$-(9-Fluorenylmethoxycarbonyl)lysine( $\boldsymbol{N}$-Boc)methyl ester (1u). ${ }^{1} \mathrm{H}$ NMR (300 MHz, $\left.\mathrm{CDCl}_{3}, 25^{\circ} \mathrm{C}\right): \delta=7.53(\mathrm{~d}, J=6.9 \mathrm{~Hz}, 2 \mathrm{H}, \operatorname{Ar} H)$, $7.33(\mathrm{~d}, J=7.5 \mathrm{~Hz}, 2 \mathrm{H}, \operatorname{Ar} H), 7.26-7.19$ (m, 4H, ArH), 5.39 (d, $J=$ $7.8 \mathrm{~Hz}, 1 \mathrm{H}, \mathrm{NH}), 4.53(\mathrm{~m}, 1 \mathrm{H}, \mathrm{NH}), 4.34-4.27(\mathrm{~m}, 3 \mathrm{H}, \alpha-\mathrm{CH}+$ $\left.\mathrm{CH}_{2 \mathrm{Fmoc}}\right), 4.17\left(\mathrm{t}, J=6.9 \mathrm{~Hz}, 1 \mathrm{H}, \mathrm{CH}_{\text {Fmoc }}\right), 3.67\left(\mathrm{~s}, 3 \mathrm{H}, \mathrm{OCH}_{3}\right), 3.04-$ $3.02\left(\mathrm{~m}, 2 \mathrm{H}, \varepsilon-\mathrm{CH}_{2}\right), 1.77$ (m, 1H, $\left.\beta-\mathrm{CH}\right), 1.63$ (m, 1H, $\left.\beta-\mathrm{CH}\right), 1.42-$ $1.16\left(\mathrm{~m}, 4 \mathrm{H}, \gamma-\mathrm{CH}_{2}+\delta-\mathrm{CH}_{2}\right), 1.36\left(\mathrm{~s}, 9 \mathrm{H}, \mathrm{C}\left(\mathrm{CH}_{3}\right)_{3}\right) \mathrm{ppm} .{ }^{13} \mathrm{C} \mathrm{NMR}$ (75 MHz, $\mathrm{CDCl}_{3}, 25^{\circ} \mathrm{C}$ ): $\delta=172.9,156.1,155.9,143.7,141.3,127.6$, 127.0, 125.1, 119.9, 80.0, 66.9, 53.7, 52.4, 47.1, 40.2, 32.1, 29.6, 28.4, 22.3. HRMS (ESI) for $\left[\left(\mathrm{C}_{27} \mathrm{H}_{34} \mathrm{~N}_{2} \mathrm{O}_{6}\right)+\mathrm{H}\right]^{+}$: calcd 483.2495 found 483.2484, 505.2306 (M $+\mathrm{Na})^{+}$.

General procedure for the $N$-Fmoc removal of amines $1 \mathrm{a}-\mathrm{i}$ in $[\mathrm{Bmim}]\left[\mathrm{BF}_{4}\right]$

To a magnetically stirred mixture of $N$-Fmoc-protected amines 1a-i $(1 \mathrm{mmol})$ and $[\mathrm{Bmim}]\left[\mathrm{BF}_{4}\right](1 \mathrm{~mL}), \mathrm{Et}_{3} \mathrm{~N}(3 \mathrm{mmol})$ was added and the mixture was stirred at ambient temperature for 4-12 min. TLC was used to monitor the reaction. Diethyl ether was added after the completion of reaction and the IL settled at the bottom. The supernatant was decanted off and the IL was washed with $\mathrm{Et}_{2} \mathrm{O}(3 \times 2 \mathrm{~mL})$. The combined $\mathrm{Et}_{2} \mathrm{O}$ extracts were acidified with an aqueous solution of $1 \mathrm{~N} \mathrm{HCl}$ and separated. The aqueous phase was then basified with sat. aq $\mathrm{NaHCO}_{3}$ and finally extracted with diethyl ether. The organic phase was dried over $\mathrm{Na}_{2} \mathrm{SO}_{4}$ and filtered. The products were isolated after evaporation of the diethyl ether to yield the free amines $\mathbf{2 a - i}$ in $80-93 \%$ yields. Spectroscopic data were compared to those of the pure products (see ESI $\dagger$ ).

\section{General procedure for the $N$-Fmoc removal of amino acid methyl esters $1 \mathbf{j}-\mathrm{q}$ in $[\mathrm{Bmim}]\left[\mathrm{BF}_{4}\right]$}

To a magnetically stirred mixture of $\mathrm{N}$-Fmoc amino acid methyl esters $\mathbf{1} \mathbf{j}-\mathbf{p}(1 \mathrm{mmol})$ and $[\mathrm{Bmim}]\left[\mathrm{BF}_{4}\right](1 \mathrm{~mL}), \mathrm{Et}_{3} \mathrm{~N}(3 \mathrm{mmol})$ was added and the mixture was stirred at ambient temperature for $12 \mathrm{~min}$. TLC was used to monitor the reaction. Diethyl ether was added after the completion of the reaction and the IL settled at the bottom. The supernatant was decanted off and the IL was washed with $\mathrm{Et}_{2} \mathrm{O}(3 \times 2 \mathrm{~mL})$. The combined $\mathrm{Et}_{2} \mathrm{O}$ extracts were acidified with an aqueous solution of $1 \mathrm{~N} \mathrm{HCl}$ and separated. The aqueous phase was then basified with sat. aq $\mathrm{NaHCO}_{3}$ and finally extracted with diethyl ether. The organic phase was dried over $\mathrm{Na}_{2} \mathrm{SO}_{4}$ and filtered. The products were isolated after evaporation of the diethyl ether to yield the free amino acid methyl ester $2 \mathbf{j}-\mathbf{p}$ in $75-88 \%$ yields. Compounds $\mathbf{2 j}-$ p were acetylated in order to perform GC/MS analysis. $\mathrm{N}$-Acetylation was achieved dissolving $2 \mathbf{j}-\mathbf{p}$ in DCM $(5 \mathrm{~mL})$ and adding acetic anhydride $(1 \mathrm{~mL})$ and a $9 \%$ aqueous solution of $\mathrm{NaHCO}_{3}$ $(5 \mathrm{~mL})$. The mixture was maintained under magnetic stirring at room temperature for $4 \mathrm{~h}$. The organic layer was separated and the aqueous phase was extracted with three additional portions of DCM $(3 \times 10 \mathrm{~mL})$. The combined organic layers were washed 
with a $9 \%$ aqueous solution of $\mathrm{NaHCO}_{3}$, twice with aqueous $\mathrm{HCl}$ $1 \mathrm{~N}$, and once with brine, and then finally dried $\left(\mathrm{Na}_{2} \mathrm{SO}_{4}\right)$. The solvent was evaporated under reduced pressure to afford the corresponding $\mathrm{N}$-acetyl derivatives $\mathbf{3} \mathbf{j}-\mathbf{p}$ as colourless oils in quantitative yield. Spectroscopic data for $\mathbf{3} \mathbf{j}-\mathbf{n}$ were comparable to those reported in the literature. ${ }^{2 a}$

$\boldsymbol{N}$-Acetyl alanine methyl ester (3j). ${ }^{1} \mathrm{H} \mathrm{NMR}\left(300 \mathrm{MHz}, \mathrm{CDCl}_{3}\right.$, $\left.25{ }^{\circ} \mathrm{C}\right): \delta=6.28(\mathrm{~s}, 1 \mathrm{H}, \mathrm{NH}), 4.58(\mathrm{~m}, 1 \mathrm{H}, \alpha-\mathrm{CH}), 3.70(\mathrm{~s}, 3 \mathrm{H}$, $\left.\mathrm{OCH}_{3}\right), 2.02\left(\mathrm{~s}, 3 \mathrm{H}, \mathrm{CH}_{3} \mathrm{CO}\right), 1.40$ (d, $\left.J=7.2 \mathrm{~Hz}, 3 \mathrm{H}, \mathrm{CH}_{3}\right) \mathrm{ppm}$. ${ }^{13} \mathrm{C}$ NMR (75 MHz, $\left.\mathrm{CDCl}_{3}, 25{ }^{\circ} \mathrm{C}\right): \delta=173.7,169.5,52.4,48.0$, 23.1, $18.6 \mathrm{ppm}$. GC/MS (EI): $m / z(\%) 145(13)\left[(\mathrm{M})^{+}\right], 102$ (86) (70), 59 (5), 44 (100). HRMS (ESI) for $\left(\left[\mathrm{C}_{6} \mathrm{H}_{11} \mathrm{NO}_{3}\right]+\mathrm{Na}\right)^{+}$: calcd 168.0637, found $168.0630[\mathrm{M}+\mathrm{Na}]^{+}$.

$\boldsymbol{N}$-Acetyl valine methyl ester (3k). ${ }^{1} \mathrm{H}$ NMR $\left(300 \mathrm{MHz}, \mathrm{CDCl}_{3}\right.$, $\left.25^{\circ} \mathrm{C}\right): \delta=6.22(\mathrm{~d}, 1 \mathrm{H}, \mathrm{NH}, J=6.6 \mathrm{~Hz}), 4.55(\mathrm{dd}, J=8.7, J=$ $5.1 \mathrm{~Hz}, 1 \mathrm{H}, \alpha-\mathrm{CH}), 3.74\left(\mathrm{~s}, 3 \mathrm{H}, \mathrm{OCH}_{3}\right), 2.13\left(\mathrm{~m}, 1 \mathrm{H}, \mathrm{CH}\left(\mathrm{CH}_{3}\right)_{2}\right)$, $2.01\left(\mathrm{~s}, 3 \mathrm{H}, \mathrm{CH}_{3} \mathrm{CO}\right), 0.93\left(\mathrm{~d}, J=6.9 \mathrm{~Hz}, 3 \mathrm{H}, \mathrm{CH}\left(\mathrm{CH}_{3}\right)_{2}\right), 0.90(\mathrm{~d}, J$ $\left.=6.9 \mathrm{~Hz}, 3 \mathrm{H}, \mathrm{CH}\left(\mathrm{CH}_{3}\right)_{2}\right) \mathrm{ppm} .{ }^{13} \mathrm{C} \mathrm{NMR}\left(75 \mathrm{MHz}, \mathrm{CDCl}_{3}, 25^{\circ} \mathrm{C}\right)$ : $\delta=172.7,170.2,57.1,52.1,31.2,23.1,18.8,17.8$ ppm. GC/MS (CI): $m / z(\%) 214(13)\left[\left(\mathrm{M}+\mathrm{C}_{3} \mathrm{H}_{5}\right)^{+}\right], 202(16)\left[\left(\mathrm{M}+\mathrm{C}_{2} \mathrm{H}_{5}\right)^{+}\right]$, $174(60)\left[(\mathrm{M}+\mathrm{H})^{+}\right], 156$ (9), 142 (65), 132 (50), 114 (100), 101 (7). HRMS (ESI) for $\left(\left[\mathrm{C}_{8} \mathrm{H}_{15} \mathrm{NO}_{3}\right]+\mathrm{H}\right)^{+}$: calcd 174.1130, found 174.1134 $[\mathrm{M}+\mathrm{H}]^{+}$.

$\boldsymbol{N}$-Acetyl leucine methyl ester (31). ${ }^{1} \mathrm{H} \mathrm{NMR}\left(300 \mathrm{MHz}, \mathrm{CDCl}_{3}\right.$, $\left.25{ }^{\circ} \mathrm{C}\right): \delta=6.50(\mathrm{~d}, J=7.68 \mathrm{~Hz}, 1 \mathrm{H}, \mathrm{NH}), 4.52(\mathrm{~m}, 1 \mathrm{H}, \alpha-\mathrm{CH}), 3.69$ (s, 3H, $\mathrm{OCH}_{3}$ ), 1.99 (s, 3H, $\left.\mathrm{CH}_{3} \mathrm{CO}\right), 1.62-1.40\left(\mathrm{~m}, 3 \mathrm{H}, \mathrm{CH}_{2} \mathrm{CH}\right.$ ), 1.40-1.26 (m, $\left.1 \mathrm{H}, \mathrm{CH}_{2}\right), 0.85-0.87\left(\mathrm{~m}, 6 \mathrm{H}, \mathrm{CH}\left(\mathrm{CH}_{3}\right)_{2}\right) \mathrm{ppm} .{ }^{13} \mathrm{C}$ NMR (75 MHz, $\left.\mathrm{CDCl}_{3}, 25{ }^{\circ} \mathrm{C}\right): \delta=173.8,170.1,52.1,50.6,41.3$, 24.7, 22.8, 22.7, $21.8 \mathrm{ppm}$. GC/MS (CI): $\mathrm{m} / z$ (\%) 228 (20) [(M + $\left.\left.\mathrm{C}_{3} \mathrm{H}_{5}\right)^{+}\right], 216(35)\left[\left(\mathrm{M}+\mathrm{C}_{2} \mathrm{H}_{5}\right)^{+}\right], 188(100)\left[(\mathrm{M}+\mathrm{H})^{+}\right], 170(5), 156$ (60), 146 (55), 128 (88), 86 (9). HRMS (ESI) for $\left(\left[\mathrm{C}_{9} \mathrm{H}_{17} \mathrm{NO}_{3}\right]+\right.$ $\mathrm{Na})^{+}$: calcd 210.1106, found $210.1103[\mathrm{M}+\mathrm{Na}]^{+}$.

$\mathrm{N}$-Acetyl isoleucine methyl ester (3m). ${ }^{1} \mathrm{H}$ NMR $(300 \mathrm{MHz}$, $\left.\mathrm{CDCl}_{3}, 25^{\circ} \mathrm{C}\right): \delta=6.06(\mathrm{~s}, 1 \mathrm{H}, \mathrm{NH}), 4.54(\mathrm{~d}, J=8.7 \mathrm{~Hz}, J=4.8 \mathrm{~Hz}$, $1 \mathrm{H}, \alpha-\mathrm{CH}), 3.67\left(\mathrm{~s}, 3 \mathrm{H}, \mathrm{OCH}_{3}\right), 1.96\left(\mathrm{~s}, 3 \mathrm{H}, \mathrm{CH}_{3} \mathrm{CO}\right), 1.78(\mathrm{~m}, 1 \mathrm{H}$, $\beta-\mathrm{CH}$ ), 1.35 (ddd, $J=7.5 \mathrm{~Hz}, J=4.8 \mathrm{~Hz}, J=4.8 \mathrm{~Hz}, 1 \mathrm{H}, \mathrm{CH}_{2}$ ), $1.12\left(\mathrm{~m}, 1 \mathrm{H}, \mathrm{CH}_{2}\right), 0.85\left(\mathrm{~s}, 3 \mathrm{H}, \mathrm{CH}_{3}\right), 0.82\left(\mathrm{~s}, 3 \mathrm{H}, \mathrm{CH}_{3}\right) \mathrm{ppm} .{ }^{13} \mathrm{C}$ NMR ( $\left.75 \mathrm{MHz}, \mathrm{CDCl}_{3}, 25{ }^{\circ} \mathrm{C}\right): \delta=172.7,169.8,56.4,51.9,37.9$, 25.2, 23.2, 15.3, $11.5 \mathrm{ppm}$. GC/MS (CI): $\mathrm{m} / z(\%) 228(51)[(\mathrm{M}+$ $\left.\left.\mathrm{C}_{3} \mathrm{H}_{5}\right)^{+}\right], 216(32)\left[\left(\mathrm{M}+\mathrm{C}_{2} \mathrm{H}_{5}\right)^{+}\right], 188(100)\left[(\mathrm{M}+\mathrm{H})^{+}\right], 157(76), 146$ (83), 128 (68), 102 (2). HRMS (ESI) for $\left(\left[\mathrm{C}_{9} \mathrm{H}_{17} \mathrm{NO}_{3}\right]+\mathrm{H}\right)^{+}$: calcd 188.1287, found 188.1279 [M+ H] $]^{+}, 210.1099[\mathrm{M}+\mathrm{Na}]^{+}$.

$\boldsymbol{N}$-Acetyl phenylalanine methyl ester (3n). ${ }^{1} \mathrm{H}$ NMR $(300 \mathrm{MHz}$, $\left.\mathrm{CDCl}_{3}, 25^{\circ} \mathrm{C}\right): \delta=7.32-7.24(\mathrm{~m}, 3 \mathrm{H}, \mathrm{ArH}), 7.09(\mathrm{dd}, J=7.9 \mathrm{~Hz}, J$ $=1.8 \mathrm{~Hz}, 2 \mathrm{H}, \operatorname{ArH}), 6.02(\mathrm{~d}, J=6.6 \mathrm{~Hz}, 1 \mathrm{H}, N \mathrm{H}), 4.88(\mathrm{dt}, J=$ $7.8 \mathrm{~Hz}, J=5.8 \mathrm{~Hz}, 1 \mathrm{H}, \alpha-\mathrm{CH}), 3.72\left(\mathrm{~s}, 3 \mathrm{H}, \mathrm{OCH}_{3}\right), 3.14(\mathrm{dd}, J=$ $13.83 \mathrm{~Hz}, J=5.7 \mathrm{~Hz}, 1 \mathrm{H}, \beta-\mathrm{CH}), 3.07(\mathrm{dd}, J=13.83 \mathrm{~Hz}, J=$ $5.7 \mathrm{~Hz}, 1 \mathrm{H}, \beta-\mathrm{CH}), 1.99$ (s, 3H, $\left.\mathrm{CH}_{3} \mathrm{CO}\right) \mathrm{ppm} .{ }^{13} \mathrm{C} \mathrm{NMR}(75 \mathrm{MHz}$, $\left.\mathrm{CDCl}_{3}, 25{ }^{\circ} \mathrm{C}\right): \delta=172.0,169.5,135.8,129.2,128.5,127.1,53.1$, 52.2 , 37.8, 23.0 ppm. HRMS (ESI) for $\left(\left[\mathrm{C}_{12} \mathrm{H}_{15} \mathrm{NO}_{3}\right]+\mathrm{Na}\right)^{+}$: calcd 244.0950, found 244.0941 [M $+\mathrm{Na}]^{+}$.

$\boldsymbol{N}$-Acetyl $\boldsymbol{N}$-methyl valine methyl ester (3o) (two rotamers). ${ }^{1} \mathrm{H}$ $\mathrm{NMR}\left(300 \mathrm{MHz}, \mathrm{CDCl}_{3}, 25{ }^{\circ} \mathrm{C}\right)$, (two rotamers): $\delta=4.88(\mathrm{~d}, 1 \mathrm{H}, J$ $=10.5 \mathrm{~Hz}, \alpha-\mathrm{CH}), 3.69$ and $3.65\left(2 \mathrm{~s}, 3 \mathrm{H}, \mathrm{OCH}_{3}\right), 2.94$ and 2.82 $\left(2 \mathrm{~s}, 3 \mathrm{H}, \mathrm{N}-\mathrm{CH}_{3}\right), 2.16$ and $2.12\left(2 \mathrm{~s}, 3 \mathrm{H}, \mathrm{CH}_{3} \mathrm{CO}\right), 2.27-2.19(\mathrm{~m}$, $1 \mathrm{H}, \beta-\mathrm{CH}), 0.95$ and $0.94\left(\mathrm{~d}, J=6.6 \mathrm{~Hz}, 3 \mathrm{H}, \mathrm{CH}\left(\mathrm{CH}_{3}\right)_{2}\right), 0.86$ and $0.82\left(\mathrm{~d}, J=6.9 \mathrm{~Hz}, 3 \mathrm{H}, \mathrm{CH}\left(\mathrm{CH}_{3}\right)_{2}\right) \mathrm{ppm} .{ }^{13} \mathrm{C} \mathrm{NMR}(75 \mathrm{MHz}$,
$\left.\mathrm{CDCl}_{3}, 25{ }^{\circ} \mathrm{C}\right): \delta=170.86,169.58,66.21,60.32,51.01,31.27$, 26.73, 21.06, 19.00, $18.82 \mathrm{ppm}$. GC/MS (CI): $\mathrm{m} / z$ (\%) 228 (51) [(M $\left.\left.+\mathrm{C}_{3} \mathrm{H}_{5}\right)^{+}\right], 216(32)\left[\left(\mathrm{M}+\mathrm{C}_{2} \mathrm{H}_{5}\right)^{+}\right], 188(100)\left[(\mathrm{M}+\mathrm{H})^{+}\right], 157$ (76), 146 (83), 128 (68), 102 (2).

$\mathrm{N}$-Acetyl $\mathbf{N}$-methyl isoleucine methyl ester (3p). ${ }^{1} \mathrm{H}$ NMR $(300$ $\mathrm{MHz}, \mathrm{CDCl}_{3}, 25^{\circ} \mathrm{C}$ ), (two rotamers): $\delta=4.99$ (d, $J=10.5 \mathrm{~Hz}, 1 \mathrm{H}$, $\alpha-\mathrm{CH}), 3.71$ and $3.67\left(2 \mathrm{~s}, 3 \mathrm{H}, \mathrm{OCH}_{3}\right), 2.95$ and $2.83(2 \mathrm{~s}, 3 \mathrm{H}, \mathrm{N}-$ $\mathrm{CH}_{3}$ ), 2.14 and 2.10 (2s, 3H, $\left.\mathrm{CH}_{3} \mathrm{CO}\right), 2.00-1.90(\mathrm{~m}, 1 \mathrm{H}, \beta-\mathrm{CH})$, 1.40-1.26 (m, 1H, $\left.\mathrm{CH}_{2}\right), 1.10-1.00\left(\mathrm{~m}, 1 \mathrm{H}, \mathrm{CH}_{2}\right), 0.97$ and 0.96 $\left(2 \mathrm{~d}, J=6.9 \mathrm{~Hz}, 3 \mathrm{H}, \mathrm{CH}_{3}\right) \mathrm{ppm}$.

$\boldsymbol{N}$-Acetyl glycine $\boldsymbol{t}$-butyl ester (3q). ${ }^{1} \mathrm{H} \mathrm{NMR}\left(300 \mathrm{MHz}, \mathrm{CDCl}_{3}\right.$, $\left.25{ }^{\circ} \mathrm{C}\right): \delta=3.92(\mathrm{~d}, J=5.1 \mathrm{~Hz}, 2 \mathrm{H}, \alpha-\mathrm{CH}), 2.04\left(\mathrm{~s}, 3 \mathrm{H}, \mathrm{CH}_{3}\right), 1.47$ (s, 9H, C( $\left.\left(\mathrm{CH}_{3}\right)_{3}\right)$, ppm. ${ }^{13} \mathrm{C} \mathrm{NMR}\left(75 \mathrm{MHz}, \mathrm{CDCl}_{3}, 25{ }^{\circ} \mathrm{C}\right): \delta=$ 170.3, 169.3, 82.3, 42.1, 28.0, 22.9 ppm. HRMS (ESI) for $\left[\left(\mathrm{C}_{8} \mathrm{H}_{15} \mathrm{NO}_{3}\right)+\mathrm{H}\right]^{+}$: calcd 174.1130, found $174.1122[\mathrm{M}+\mathrm{H}]^{+}$, 196.0945 [M $+\mathrm{Na}]^{+}$.

$\boldsymbol{N}$-Acetyl phenylalanine benzyl ester (3r). ${ }^{1} \mathrm{H}$ NMR $(300 \mathrm{MHz}$, $\left.\mathrm{CDCl}_{3}, 25{ }^{\circ} \mathrm{C}\right): \delta=7.35-7.21(\mathrm{~m}, 8 \mathrm{H}, \mathrm{ArH}), 7.00-6.97(\mathrm{~m}, 2 \mathrm{H}$, $\operatorname{Ar} H), 6.02$ (d, $J=6.9 \mathrm{~Hz}, 1 \mathrm{H}, \mathrm{NH}), 5.14-5.13\left(\mathrm{~m}, 2 \mathrm{H}, \mathrm{COOCH}_{2}\right.$ ), $4.93(\mathrm{~m}, 1 \mathrm{H}, \alpha-\mathrm{CH}), 3.12-3.09\left(\mathrm{~m}, 2 \mathrm{H}, \mathrm{CH}_{2} \mathrm{Ph}\right), 1.96(\mathrm{~s}, 3 \mathrm{H}$, $\left.\mathrm{CH}_{3} \mathrm{CO}\right) \mathrm{ppm} .{ }^{13} \mathrm{C} \mathrm{NMR}\left(75 \mathrm{MHz}, \mathrm{CDCl}_{3}, 25{ }^{\circ} \mathrm{C}\right): \delta=171.7,169.9$, 135.8, 135.2, 129.4, 128.8, 128.7, 128.6, 127.2, 67.4, 53.3, 37.9, 23.2 ppm. HRMS (ESI) for $\left[\left(\mathrm{C}_{18} \mathrm{H}_{19} \mathrm{NO}_{3}\right)+\mathrm{H}\right]^{+}$: calcd 298.1443, found 298.1437 $[\mathrm{M}+\mathrm{H}]^{+}, 320.1254[\mathrm{M}+\mathrm{Na}]^{+}$.

$\boldsymbol{N}$-Acetyl tyrosine $\left(\boldsymbol{O}\right.$ - $\boldsymbol{t}$-butyl) $\boldsymbol{t}$-butyl ester (3s). ${ }^{1} \mathrm{H}$ NMR $(300$ $\left.\mathrm{MHz}, \mathrm{CDCl}_{3}, 25^{\circ} \mathrm{C}\right): \delta=7.31(\mathrm{~d}, J=8.4 \mathrm{~Hz}, 2 \mathrm{H}, \mathrm{ArH}), \delta=7.90(\mathrm{~d}$, $J=8.4 \mathrm{~Hz}, 2 \mathrm{H}, \mathrm{ArH}), 6.04$ (br s, s, $1 \mathrm{H}, \mathrm{NH}), 4.74$ (dd, $J=6.6 \mathrm{~Hz}, J$ $=5.7 \mathrm{~Hz}, 1 \mathrm{H}, \alpha-\mathrm{CH}), 3.09-3.02(\mathrm{~m}, 2 \mathrm{H}, \beta-\mathrm{CH}), 2.02(\mathrm{~s}, 3 \mathrm{H}$, $\left.\mathrm{CH}_{3} \mathrm{CO}\right), 1.38\left(\mathrm{~s}, 9 \mathrm{H}, \mathrm{C}\left(\mathrm{CH}_{3}\right)_{3}\right), 1.40\left(\mathrm{~s}, 9 \mathrm{H}, \mathrm{C}\left(\mathrm{CH}_{3}\right)_{3}\right)$, ppm. ${ }^{13} \mathrm{C}$ NMR (75 MHz, $\left.\mathrm{CDCl}_{3}, 25{ }^{\circ} \mathrm{C}\right): \delta=170.9,169.3,146.4,131.1$, 129.9, 124.0, 90.8, 82.4, 53.6, 37.5, 28.8, 27.9, 23.2 ppm. HRMS (ESI) for $\left[\left(\mathrm{C}_{19} \mathrm{H}_{29} \mathrm{NO}_{4}\right)+\mathrm{H}\right]^{+}$: calcd 336.2175, found 336.2133 [M $+\mathrm{H}]^{+}, 358.1987[\mathrm{M}+\mathrm{Na}]^{+}$.

$\boldsymbol{N}$-Acetyl glutamic acid(O-t-butyl)methyl ester (3t). ${ }^{1} \mathrm{H}$ NMR $\left(300 \mathrm{MHz}, \mathrm{CDCl}_{3}, 25{ }^{\circ} \mathrm{C}\right): \delta=6.34(\mathrm{~d}, J=7.5 \mathrm{~Hz}, 1 \mathrm{H}, \mathrm{NH}), 4.74$ $(\mathrm{dt}, J=8.0 \mathrm{~Hz}, J=5.1 \mathrm{~Hz}, 1 \mathrm{H}, \alpha-\mathrm{CH}), 3.67\left(\mathrm{~s}, 3 \mathrm{H}, \mathrm{OCH}_{3}\right), 2.35-$ $2.15\left(\mathrm{~m}, 2 \mathrm{H}, \beta-\mathrm{CH}_{2}\right.$ ), 2.05 (ddd, $J=14.1 \mathrm{~Hz}, J=7.3 \mathrm{~Hz}, J=$ $2.2 \mathrm{~Hz}, 1 \mathrm{H}, \gamma-\mathrm{CH}$ ), 1.95 (s, 3H, $\mathrm{CH}_{3} \mathrm{CO}$ ), 1.87 (ddd, $J=14.1 \mathrm{~Hz}, J$ $=6.1 \mathrm{~Hz}, J=1.3 \mathrm{~Hz}, 1 \mathrm{H}, \gamma-\mathrm{CH}), 1.37\left(\mathrm{~s}, 9 \mathrm{H}, \mathrm{C}\left(\mathrm{CH}_{3}\right)_{3}\right) \mathrm{ppm} .{ }^{13} \mathrm{C}$ $\mathrm{NMR}\left(75 \mathrm{MHz}, \mathrm{CDCl}_{3}, 25^{\circ} \mathrm{C}\right): \delta=172.6,172.2,170.0,80.8,52.4$, $51.8,31.4,28.0,27.2,23.0 \mathrm{ppm}$. HRMS (ESI) for $\left[\left(\mathrm{C}_{12} \mathrm{H}_{21} \mathrm{NO}_{5}\right)+\right.$ $\mathrm{Na}]^{+}$: calcd 282.1317, found 282.1307 $[\mathrm{M}+\mathrm{Na}]^{+}$.

$\boldsymbol{N}$-Acetyl lysine( $\boldsymbol{N}$-Boc)methyl ester (3u). ${ }^{1} \mathrm{H}$ NMR $(300 \mathrm{MHz}$, $\left.\mathrm{CDCl}_{3}, 25^{\circ} \mathrm{C}\right):{ }^{1} \mathrm{H}$ NMR $\left(300 \mathrm{MHz}, \mathrm{CDCl}_{3}, 25^{\circ} \mathrm{C}\right): \delta=6.48(\mathrm{~d}, J=$ $7.5 \mathrm{~Hz}, 1 \mathrm{H}, \mathrm{NH}), 4.73(\mathrm{~m}, 1 \mathrm{H}, \mathrm{NH}), 4.50(\mathrm{dd}, J=12.6 \mathrm{~Hz}, J=$ $7.5 \mathrm{~Hz}, 1 \mathrm{H}, \alpha-\mathrm{CH}), 3.67\left(\mathrm{~s}, 3 \mathrm{H}, \mathrm{OCH}_{3}\right), 3.04-2.99\left(\mathrm{~m}, 2 \mathrm{H}, \varepsilon-\mathrm{CH}_{2}\right)$, 1.96 (s, 3H, $\mathrm{CH}_{3} \mathrm{CO}$ ), $1.75(\mathrm{~m}, 1 \mathrm{H}, \beta-\mathrm{CH}), 1.58$ (m, 1H, $\beta-\mathrm{CH}$ ), 1.44-1.27 (m, 4H, $\left.\gamma-\mathrm{CH}_{2}+\delta-\mathrm{CH}_{2}\right), 1.36\left(\mathrm{~s}, 9 \mathrm{H}, \mathrm{C}\left(\mathrm{CH}_{3}\right)_{3}\right) \mathrm{ppm} .{ }^{13} \mathrm{C}$ NMR (75 MHz, $\left.\mathrm{CDCl}_{3}, 25{ }^{\circ} \mathrm{C}\right): \delta=172.1,169.1,155.2,78.1,51.3$, 51.1, 38.9, 30.8, 28.6, 27.4, 21.9, 21.4 ppm. HRMS (ESI) for $\left[\left(\mathrm{C}_{14} \mathrm{H}_{26} \mathrm{~N}_{2} \mathrm{O}_{5}\right)+\mathrm{H}\right]^{+}$: calcd 303.1920, found $303.1904[\mathrm{M}+\mathrm{H}]^{+}$, $325.1737[\mathrm{M}+\mathrm{Na}]^{+}$.

\section{Recycling of $[\mathrm{Bmim}]\left[\mathrm{BF}_{4}\right]$ in the synthesis of $2 \mathrm{a}$}

At the end of the first experiment and after the recovery of the free aniline, the IL was treated with $5 \%$ aqueous $\mathrm{HCl}(2 \mathrm{~mL})$ and 
subjected to consecutive extractions with ethyl acetate and diethyl ether. The ionic liquid was recovered by removing water under vacuum. The IL was finally dried at $100{ }^{\circ} \mathrm{C}$ for $1 \mathrm{~h}$ and reused for the next run without any significant loss in its efficiency ( 88 and $89 \%$ yields).

\section{Conflict of interest}

There are no conflicts of interest to declare.

\section{Acknowledgements}

This work was supported by grants from MIUR (MinisteroItaliano dell'Università e della Ricerca, ex-60\% funds).

\section{Notes and references}

1 P. J. Kocienski, Protecting Groups, Georg Thieme Verlag, New York, 3rd edn, 2005.

2 (a) R. De Marco, M. L. Di Gioia, A. Leggio, A. Liguori and M. C. Viscomi, Eur. J. Org. Chem., 2009, 3795-3800; (b) A. Procopio, G. Cravotto, M. Oliverio, P. Costanzo, M. Nardi and R. Paonessa, Green Chem., 2011, 13, 436-443; (c) M. Nardi, A. Cozza, L. Maiuolo, M. Oliverio and A. Procopio, Tetrahedron Lett., 2011, 52, 4827-4834; (d) M. Nardi, A. Cozza, A. De Nino, M. Oliverio and A. Procopio, Synthesis, 2012, 44, 800-804; (e) M. Oliverio, P. Costanzo, R. Paonessa, M. Nardi and A. Procopio, RSC Adv., 2013, 3, 2548-2552; (f) A. De Nino, L. Maiuolo, M. Nardi, R. Pasceri, A. Procopio and B. Russo, Arabian J. Chem., 2016, 9, 32-37; (g) M. Nardi, N. H. Cano, A. De Nino, M. L. Di Gioia, L. Maiuolo, M. Oliverio, A. Santiago, D. Sorrentino and A. Procopio, Tetrahedron Lett., 2017, 58, 1721-1726.

3 (a) A. Isidro-Llobet, M. Álvarez and F. Albericio, Chem. Rev., 2009, 109, 2455-2504; (b) M. Nardi, N. H. Cano, P. Costanzo, M. Oliverio, G. Sindona and A. Procopio, $R S C$ Adv., 2015, 5(24), 18751-18760.

4 (a) M. Bayermann, M. Bienert, H. Niedrich, L. A. Carpino and D. Sadat-Aalaee, J. Org. Chem., 1990, 55, 721-728; (b) L. A. Carpino, D. Sadat-Aalaee and M. Beyermann, J. Org. Chem., 1990, 55, 1673-1675; (c) F. Alberho, N. KneibCordonier, S. Biancalana, L. Gera, R. I. Masada, D. Hudson and G. Barany, J. Org. Chem., 1990, 55, 3730-3743; (d) E. Atherton, H. Fox, D. Harktss, C. J. Logan, R. C. Sheppard and B. J. Wilhams, Chem. Commun., 1978, 537-539; (e) E. Atherton, H. Fox, D. Harkiss and R. C. Sheppard, Chem. Commun., 1978, 539-540; (f) C.-D. Chang, A. M. Felix, M. H. Jimenez and J. Meienhofer, Int. J. Pept. Protein Res., 1980, 15, 485-494.

5 (a) N. Zinieris, L. Leondiadis and N. Ferderigos, J. Comb. Chem., 2005, 7, 4-6; (b) C. F. Vergel Galeano, Z. J. Rivera Monroy, J. E. Rosas Pérez and J. E. García Castañeda, J. Mex. Chem. Soc., 2014, 58(4), 386-392.

6 Proceedings of the 31st European Peptide Symposium, ed. M. Lebl, M. Meldal, K. J. Jensen and T. Hoeg-Jensen, European Peptide Society, 2010.
7 K. Ralhan, V. G. KrishnaKumara and S. Gupta, RSC Adv., 2015, 5, 104417-104425.

8 L. A. Carpino, Acc. Chem. Res., 1987, 20, 401-407.

9 N. Zinieris, L. Leondiadis and N. Ferderigos, J. Comb. Chem., 2005, 7, 4-6.

10 (a) D. Orain, J. Ellard and M. Bradley, J. Comb. Chem., 2002, 4, 1-16; (b) J. Hachmann, J. Comb. Chem., 2006, 8(2), 149; (c) C. Chen, B. Rajagopal, X. Yu Liu, K. Lin Chen, Y. C. Tyan, F. Lin and P. C. Lin, Amino Acids, 2014, 46, 367-374.

11 (a) P. T. Anastas and J. C. Warner, Green Chemistry: Theory and Practice, Oxford University Press, New York, 1998, p. 30; (b) P. T. Anastas and M. M. Kirchhoff, Acc. Chem. Res., 2002, 35, 686-694; (c) M. Nardi, N. Herrera Cano, P. Costanzo, M. Oliverio, G. Sindona and A. Procopio, $R S C$ $A d v ., \quad 2015, \quad 5$, 18751-18760; (d) N. Herrera Cano, J. G. Uranga, M. Nardi, A. Procopio, D. A. Wunderlin and A. N. Santiago, Beilstein J. Org. Chem., 2016, 12, 2410-2419.

12 (a) M. J. Earle, P. B. McCormac and K. R. Seddon, Chem. Commun., 1998, 2245-2246; (b) F. Liu, M. B. Abrams, R. T. Baker and W. Tumas, Chem. Commun., 2001, 433434; (c) E. D. Bates, R. D. Mayton, I. Ntai and J. H. Davis, J. Am. Chem. Soc., 2001, 124, 926-927; (d) J. M. Xu, Q. Wu, Q. Y. Zhang, F. Zhang and X. F. Lin, Eur. J. Org. Chem., 2007, 1798-1802; (e) B. C. Ranu, A. Saha and R. Dey, Curr. Opin. Drug Discovery Dev., 2010, 13, 658-668; $(f)$ A. K. Chakraborti and S. Raha Roy, J. Am. Chem. Soc., 2009, 131, 6902-6903; $(g)$ A. De Nino, L. Maiuolo, P. Merino, M. Nardi, A. Procopio, D. Roca-Lopez, B. Russo and V. Algieri, ChemCatChem, 2015, 7, 830-835.

13 (a) P. Wasserscheid and T. Welton, Ionic Liquids in Synthesis, Wiley-VCH, 2004; (b) M. A. P. Martins, C. P. Frizzo, D. N. Moreira, N. Zanatta and H. G. Bonacorso, Chem. Rev., 2008, 108, 2015-2050; (c) J. Dupont and J. Spencer, Angew. Chem., Int. Ed., 2004, 43, 5296-5297; (d) J. Ranke, S. Stolte, R. Storman, J. Arning and B. Jastor, Chem. Rev., 2007, 107, 2183-2206; (e) K. Alfonsi, J. Colberg, P. J. Dunn, T. Fevig, S. Jennings, T. A. Johnson, H. P. Kleine, C. Knight, M. A. Nagy, D. A. Perry and M. Stefaniak, Green Chem., 2008, 10, 31-36; (f) Q. Zhang, S. Zhang and Y. Deng, Green Chem., 2011, 13, 2619-2637; (g) P. Dominguez de Maria, Angew. Chem., Int. Ed., 2008, 47, 6960-6968; (h) D. Coleman and N. Gathergood, Chem. Soc. Rev., 2010, 39, 600-637; (i) S. Majumdar, J. De, A. Chakraborty, D. Roy and D. K. Maiti, RSC Adv., 2015, 5, 3200-3205.

14 (a) M. L. Di Gioia, A. Barattucci, P. Bonaccorsi, A. Leggio, L. Minuti, E. Romio, A. Temperini and C. Siciliano, $R S C$ Adv., 2014, 4, 2678-2686; (b) M. L. Di Gioia, A. Gagliardi, A. Leggio, V. Leotta, E. Romio and A. Liguori, RSC Adv., 2015, 5, 63407-63420.

15 (a) C.-D. Chang, M. Waki, M. Ahmad, J. Meienhofer, E. O. Lundell and J. D. Haug, Int. J. Pept. Protein Res., 1980, 15, 59-66; (b) G. B. Fields, Methods Mol. Biol., 1994, 35, 1727.

16 D. Millán, M. Rojas, J. G. Santos, J. Morales, M. Isaacs, C. Diaz and P. Pavez, J. Phys. Chem. B, 2014, 118, 4412-4418.

17 (a) M. L. Di Gioia, A. Leggio, A. Liguori, F. Perri, C. Siciliano and M. C. Viscomi, Amino Acids, 2010, 38, 133-143; (b) 
E. Belsito, R. De Marco, M. L. Di Gioia, A. Liguori, F. Perri and M. C. Viscomi, Eur. J. Org. Chem., 2010, 4245-4252; (c) R. De Marco, M. L. Di Gioia, A. Liguori, F. Perri, C. Siciliano and M. Spinella, Tetrahedron, 2011, 67, 97089714; (d) C. Siciliano, A. Barattucci, P. Bonaccorsi, M. L. Di Gioia, A. Leggio, L. Minuti, E. Romio and A. Temperini, J. Org. Chem., 2014, 79(11), 5320-5326; (e) M. L. Di Gioia, A. Leggio, F. Malagrinò, E. Romio, C. Siciliano and A. Liguori, Mini-Rev. Med. Chem., 2016, 16, 683-690.

18 (a) R. De Marco, M. L. Di Gioia, A. Leggio, A. Liguori, F. Perri, C. Siciliano and M. C. Viscomi, Amino Acids, 2010, 38, 691700; (b) A. Leggio, D. Alò, E. L. Belsito, M. L. Di Gioia, E. Romio, C. Siciliano and A. Liguori, J. Pept. Sci., 2015, 21(8), 644-650; (c) M. L. Di Gioia, E. L. Belsito, A. Leggio,
V. Leotta, E. Romio, C. Siciliano and A. Liguori, Tetrahedron Lett., 2015, 56, 2062-2066.

19 (a) Y. E. Jad, T. Govender, H. G. Kruger, A. El-Faham, B. G. de la Torre and F. Albericio, Org. Process Res. Dev., 2017, 21, 365-369; (b) Y. Jad, G. Acosta, S. Khattab, B. Torre, T. Govender, H. Kruger, A. El-Faham and F. Albericio, Amino Acids, 2016, 48, 419-426; (c) Y. E. Jad, G. A. Acosta, T. Govender, H. G. Kruger, A. El-Faham, B. de la Torre and F. Albericio, ACS Sustainable Chem. Eng., 2016, 4, 6809-6814. 20 J. C. Plaquevent, J. Levillain, F. Guillen, C. Malhiac and A. C. Gaumont, Chem. Rev., 2008, 108, 5035-5060.

21 (a) W. Miao and T. H. Chan, Acc. Chem. Res., 2006, 39, 897908; (b) W. Miao and T. H. Chan, J. Org. Chem., 2005, 70(8), 3251-3255. 